\title{
感潮 河口流の密度構造
}

\section{1. 序文}

野外におけるほとえどの河口二層流は, 何某かの潮汐 の影響を受け, 周期的に先の流れの状態や成層構造を変 えてゆく.もちろん, 潮差が十分に小さければ, 流れの 状態定常に近く, 従来からある, 定常流における, 塩 水楔の形状を表現する式や，河口流出後の流況に関する 研究の結果が, すべて, 適用可能となり,したがって, 成層密度構造も明らかとなる。しかし, 潮差が著しく大 きい場合には，混合も伴うようになり事柄が非常に複雑 になる. 本論文は, こうした，両極の状態をも含めた， 感潮河口二層流の密度構造の変化を支配する要因をさぐ り，その構造を表現する適切なパラメーターの導出を試 みたものである.

\section{2. 従来の結果における問題点の検討}

河床が平滑で混合が無視できる場合の密度構造は, 界 面の形状のみ分かれば知ることができるが，この点に関 しては柏村・吉田による多くの研究（たとえば, 第 13〜 20，23，24 回海講講演集及び論文集）があり，実験およ び，野外観測を通じて，かなり詳細な知識が得られてい る.ただ，彼らの研究に打いては，河口に抢ける流速を 河口条件として知られる $F_{i 0}=1 （ F_{i 0}$ : 河口における内 部フルード数) から得て考察が進められており, 現実に 忠実でない部分があった. 吉田・柏村 ${ }^{1)}$ は，特に，微少 流量の実験において，上述の手法に問題の生ずることを 指摘し，実際の流速值を用いて，それまでの河口流出流 況のパラメーターを再検討した. 同様の修正は, 従来, やはり河口条件を利用してまとめた混合が無視できる場 合の非定常河口流出流況の支配パラメーター $\lambda^{2), 3), 4)}$ に 対しても施されるべきである，そこで，まずこの修正を 行って打こう.

流況を支配するパラメーターとしては，河口での定常 流下の淡水流速 (断面平均值) $U_{10}$ と, 潮汐による变動 流速振幅 $u_{10}$ で構成される次の量

$$
\lambda_{0}=u_{10} / U_{10}
$$

が適当と思われる， $\lambda_{0}$ の意味するところは， $u_{10}$ が大き くなるにつれて， $U_{10}$ に与える影響も大きくなり， $\lambda_{0}>1$ では淡水の流れが逆流に至ることを暗示しており，その 值は，流況にも逐一対応している，ここでは $U_{10}$ を河口 条件から求めず，実測值を使用することになる。しか し, $u_{10}$ については, 理論結果と実測値の一致度が良い ので, 以下の理論結果から求める.

$$
u_{10}=K g \eta_{10} / C_{s}
$$

ここで, $C_{s}, g, \eta_{10}$ はそれぞれ表面波速, 重力加速度, 潮汐振幅である. \&た, $K$ は進行波性の水路に対しては 1 と括けるが，定常波性のそれに対しては

$$
K=|\tan k l|=2 \pi l / T C_{s}
$$

$(l:$ 水路全長, $T:$ 周期 $)$ とする必要がある.なお， $U_{10}$ については, $F_{i 0}=1$ とは限らないという事実に基づき, これに実測値を使用するなら

$$
U_{10}=\frac{Q}{b_{0} h_{10}}=\left(\frac{\varepsilon g Q}{b_{0}} F_{i 0}\right)^{1 / 3}
$$

から得ることもできる.ここに， $b_{0}, h_{10}, Q$ は，それぞ れ, 河道の幅 (一定), 河口での淡水厚さ, 流量であり, $\varepsilon=\left(\rho_{2}-\rho_{1}\right) / \rho_{2}, \rho_{1}, \rho_{2}$ は上, 下層の密度である. かくし $\tau(1) \sim(4)$ 式から最終的に

$$
\lambda_{0}=K \frac{g \eta_{10}}{C_{s}}\left(\frac{b_{0}}{\varepsilon g Q F_{i 0}^{2}}\right)^{1 / 3}
$$

と求まる. この $\lambda_{0}$ を用いて, 従来の淡一塩二層流の河 口流出流況 5) 整理し直し,さらに, 新たに得た野外の 結果（石狩川, 天塩川）をも付加すると，図一1 に示す 分類が可能である. 図中 $\theta_{0}=(\varepsilon g \nu)^{1 / 3} / U_{10}$ はクーリガン 数である.この結果のうち, 実験により得た分を, さら に詳細に表現すると, 以下のごとくである (以下の表現 は, 混合が無視できれば, 野外の結果にも適用できる).

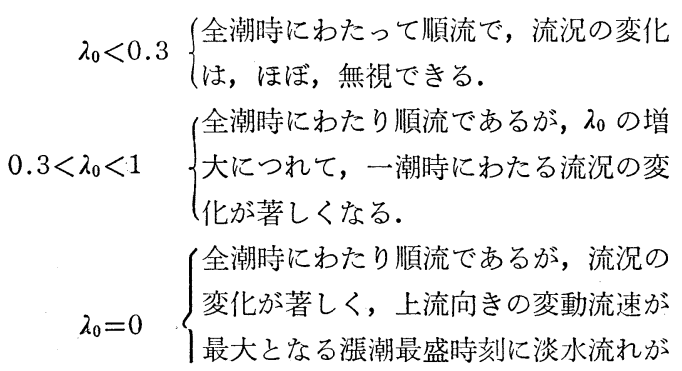




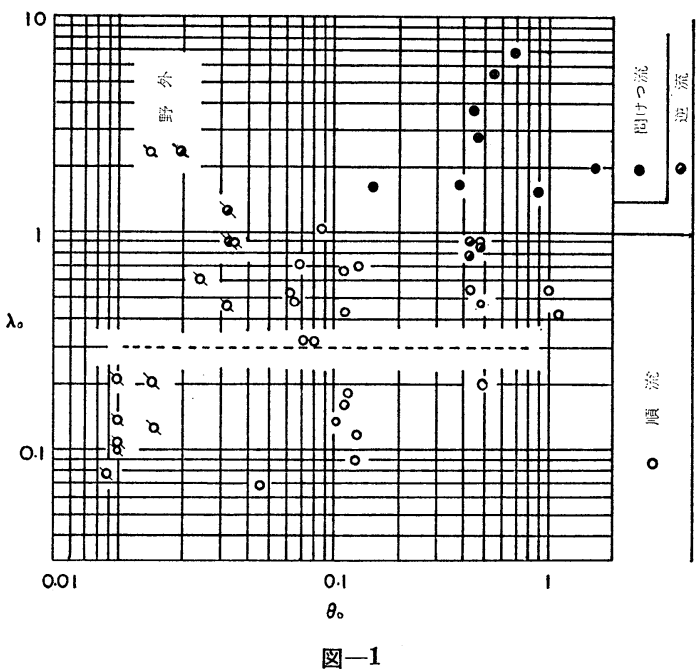

〈停止する. $1.0<\lambda_{0}<1.4\left\{\begin{array}{l}\lambda_{0} \text { の増大につれて, 逆流の見られる時 } \\ \text { 間が長くなる. }\end{array}\right.$

(河口では, 上流向きの変動流速が最大 值を示す頃に下層塩水が表面に露出す $\lambda_{0}>1.4\left\{\right.$ る. この領域は, $\lambda_{0}$ の堌大につれて拡 大し，露出時間も長くなる. 淡水の流 出は落潮期のみとなりその流出形式は 間けつ的である.

上述の修正を施した従来の研究を総合すれば，河床に 粗度要素のない場合の河口二層流の密度構造と潮汐の関 係がほぼ明らかになる，ただ，未だに野外の河口で見出 される潮汐周期の内部波の発生機構が明らかでないため に，この効果它含めた高精度の密度構造の予測はできな いことを指摘して打かなねばらない。

\section{3. 感潮河口ニ層流の混合機構}

潮差が大きければ，二層の混合が促進されるのが当然 のことのように思われがちである。しかし，なぜそうな るのかという問には，未だ十分な答が用意できているわ けではない，ただ，界面近傍のせん断流不安定によるか (internal mixing), または，河床上に発達する乱流に基 づくか (external mixing) のいずれかであろうという予測 は立つ. 吉田6) によれば，河床の粗度要素から生ずるス パイラル渦が界面を破壞することが明らかになって扔 り，前者がいわゆる強混合形式をもたらすほどの界面破 壊の原因となることはないようである，実際に，無限小 振幅波の成長率を計算してみても（直線化された密度招 よび流速分布を有する 4 層モデルを適用した), 非粘性 的には成長し得るが，粘性等の減衰効果を考慮すると， 界面波の不安定による成長は望めないことが分かる。こ の原因は，いかに潮差だけが大きくなろうとも変動流速
の振幅が大きくなるだけで二層間の相対速度があまり大 きくなり得ないことにある，同様のことは沖合の二層の 混合についてもいえる，ただ，沖合では水深が大きくな っているので, 海底の粗度要素の影響が無く, 専ら, 河 道で発生した粗度要素による渦が沖合の一時加速の界面 を破壊することになる(写真一1 (1))。もちろえ，こうし た場面は，落潮時の久観測され，浱潮時にはその渦の影 響もなく，界面は著しく安定化する（写真一1 (2)).

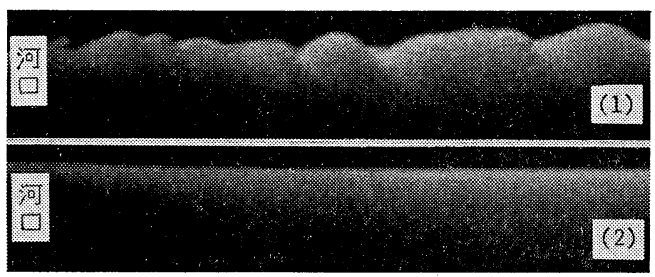

写真-1

\section{4. 河床粗度要素後流境界に発生する渦の発生 条件}

潮汐による河口二層流の混合状態を表現し得るパラメ ーターを導出する場合，すべての要因について，実験を 積み重ねることが必要である。しかし，この方法は，問 題にかかわる要素があまりにも多すぎ，効率のよい実駼 が望まれる，そのためには，混合機構を十分に明らかに しておか叔ばならない。こうした観点から，本節では， スパイラル渦の発生条件や，その渦と界面破壊の関係も 詳細に調べておく.

断面が $0.6 \mathrm{~cm} \times 0.6 \mathrm{~cm}$ の単一の角柱を河床に扮い て，流れに沿う，その近傍での流速分布を LDV で測定 すると，図一2の結果を得る。な抢，全水深は $4.0 \mathrm{~cm}$

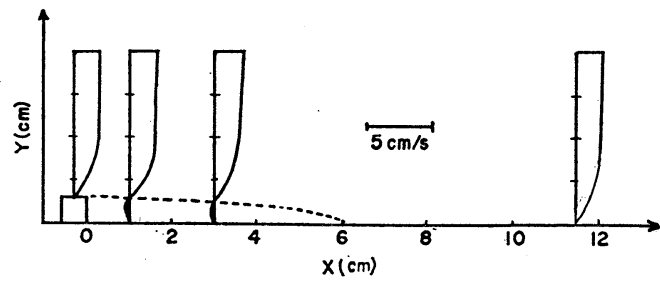

図-2

で水道水のみを定常的に流した場合の結果であり，流量 は，スパイラル渦が発生し始める臨界状態になるように 調節されている. スパイラル渦は粗度要素後方約 $2.0 \mathrm{~cm}$ で発生しその波長は約 $3.0 \mathrm{~cm}$ であった。速度分布か ら，渦発生点での諸量を推定し，Tatumi and Gotoh の 定義に従ってレイノルズ数 $R$ と波数 $k_{*}$ 学求めると 図一3 に示吉結果を得る. 図中○印がその結果で，他の 印は潮汐を与えた場合の渦発生時の結果（臨界状態とは 


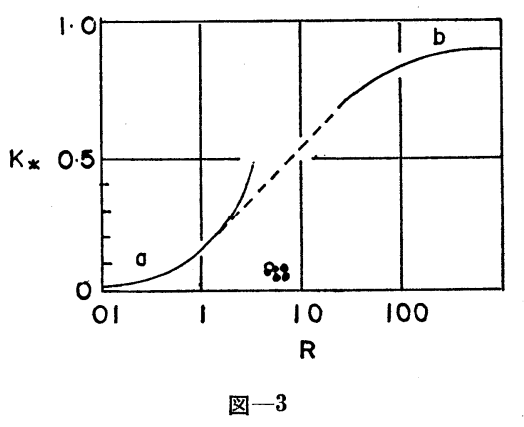

限らない)，そして， $a ， b$ は，それぞれ Tatumi and Gotoh $^{7)}$ と Lessen ${ }^{8)}$ が導いた中立曲線である。なお， $R=0.310 \sqrt{x U_{0} / \nu}, L=R \nu / U_{0}, k_{*}=2 \pi L / l_{w}, l_{w}$ : 波長, $L: R$ の代表長さ， $U_{0}$ ：自由境界層を境とする上下層の 相対速度の半分值, $x$ : 粗度要素端からの距離である. 図一3 は, 潮汐のように, 波長の長い非定常流の場合に は, 定常流のもとで得られる結果と, ほぼ, 一致するこ とを示している，とこで，この事実を利用し，粗度を変 えた場合の㵝発生条件を, 定常流のもとで求め, 非定常 流時のそれとしよう。粗度要素間隔を $10 \mathrm{~cm}, 5 \mathrm{~cm}$, 粗度 高さを $1.2 \mathrm{~cm}, 1.8 \mathrm{~cm}$ と変えてみた場合，いずれの場 合にも, 渦発生のレイノルズ数は 4.5 5.7 とあまり変 化せず， $k_{*}$ も $0.07 \sim 0.10$ のせまい範囲内におさまる. このことは，不安定波の発生因が自由境界層の不安定に よるものであることを裏づけているとともに, 上述の粗 度の状態下では，その境界層が渦発生に十分なだけ成長 できることを示している。これに対し，粗度要素間隔を $2.5 \mathrm{~cm}$ にせばめると, 粗度要素と渦発生点の間に次の 要素がくることになり，境界層の不安定は，さらに，大 きな $R$ に対してしか生じ得なくなる．渦発生が自由境 界層の成長に関係するということは，粗度間隔のみなら ず高さにも関係するという事を暗示しているが，これは 事実であって, その効果は, 渦の直径が粗度高さの 2 倍 程度にしかならないという結果になって現われる。

以上の結果をふまえて，次節では，潮汐によって界面 が破壞する条件を調べてみる。

\section{5. 粗度要素間隔と混合型式}

$\varepsilon=0.003, Q=10 \mathrm{cc} / \mathrm{s}, \eta_{10}=1.0 \mathrm{~cm}$ とし, 水平に招 かれた水路部の全水深が $4 \mathrm{~cm}$ という条件下で，粗度間 隔と混合の関係学調べてみると，写真一2 (1)〜 (6) に示 される定性的な結果を得る、いずれの写真も碾潮最盛時 の場面を示しており，粗度要素は $0.6 \mathrm{~cm} \times 0.6 \mathrm{~cm}$ の断 面と, 写真に記入された $S$ で示される高さを有してい る.また，観測は河口上流約 $1 \mathrm{~m}$ の地点で行われてい る.（1）は先に述べたスパイラル渦，(2) は単一要素の 場合で，その後流域に界面破填が生じた場合である.し かし，さらに遠い後流域ではこの破壊もおさまり，明確

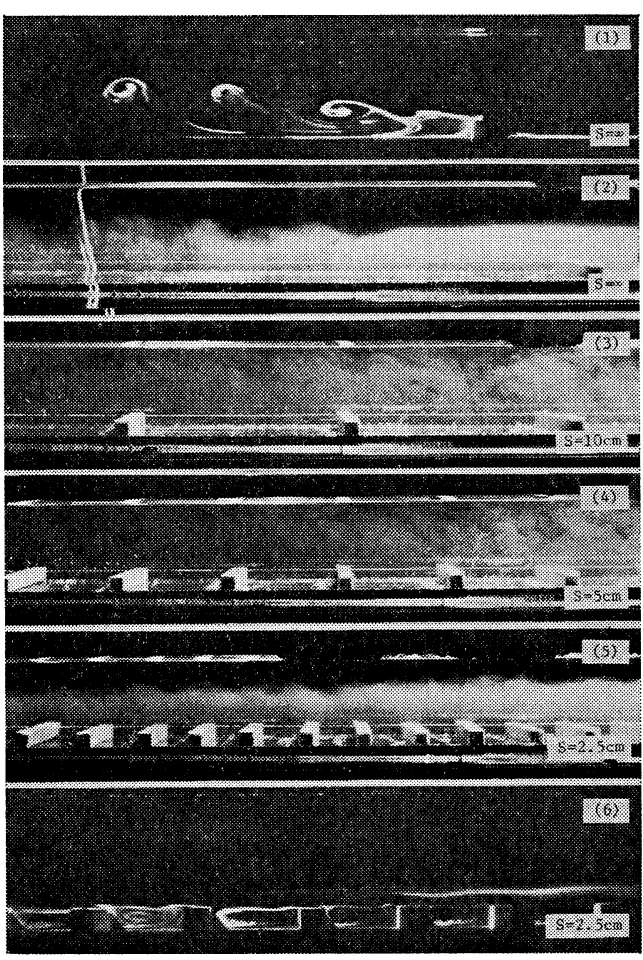

写真-2

な二層が形成されているとれに対し（3）では一見して 強い混合型式になっていることがわかる。この状態は （4）においても見られ，混合のためには，ある程度粗度 間隔をせまくする必要のあることが分かる，しかし，さ らに（5）のごとくせまくすると，もはやスパイラル渦が 発達せず，界面もきわめて安定化する，この場合には， 同じ粗度間隔に怙ける要素間の流れを可視化した (6) か ら分かるように要素間のサーキューレーションが，むし ろ, 粗度の平滑化に役立っている. ところで, 最も混合 の著しい(3) の場合の $S / H(H$ : 粗度高さ) は 16.7 で ある.この值は，いわゆる相当粗度 ${ }^{9}$ が最大值を示す角 柱の $S / H$ の值にきわめて近く, 上述の物理的な内容が, 後者の結果と密接に関係していることが分かる. 以上の 定性的な結果は，先に検討した粗度とスパイラル渦の発 生状況とほぼ符合している。

\section{6. $\lambda_{0}, \theta_{0}$ による混合型式の分類}

次に, $\lambda_{0}$ と $\theta_{0}$ そ様々に変え, 混合形状がどのように 分類されるか見てみる。実験は，粗度要素断面 $0.6 \mathrm{~cm}$ $\times 0.6 \mathrm{~cm}$, 間隔 $S=10 \mathrm{~cm}$, 水路全長 $l=536 \mathrm{~cm}$, 全水 深 $4 \mathrm{~cm}, \varepsilon=0.0057$ 及び $0.0064, \eta_{10}=0.5 \mathrm{~cm}$ の条件 下で行い， $\theta$ については, 流量 $Q$ を $15.0 \mathrm{cc} / \mathrm{s}, 21.0$ $\mathrm{cc} / \mathrm{s}, 27.0 \mathrm{cc} / \mathrm{s}$ と変化させることによってその值を変え る. 観測の結果は図一4に示されている。なお，分類は 漲潮最盛時の観測と, 実際の密度分布の測定を通じて行 

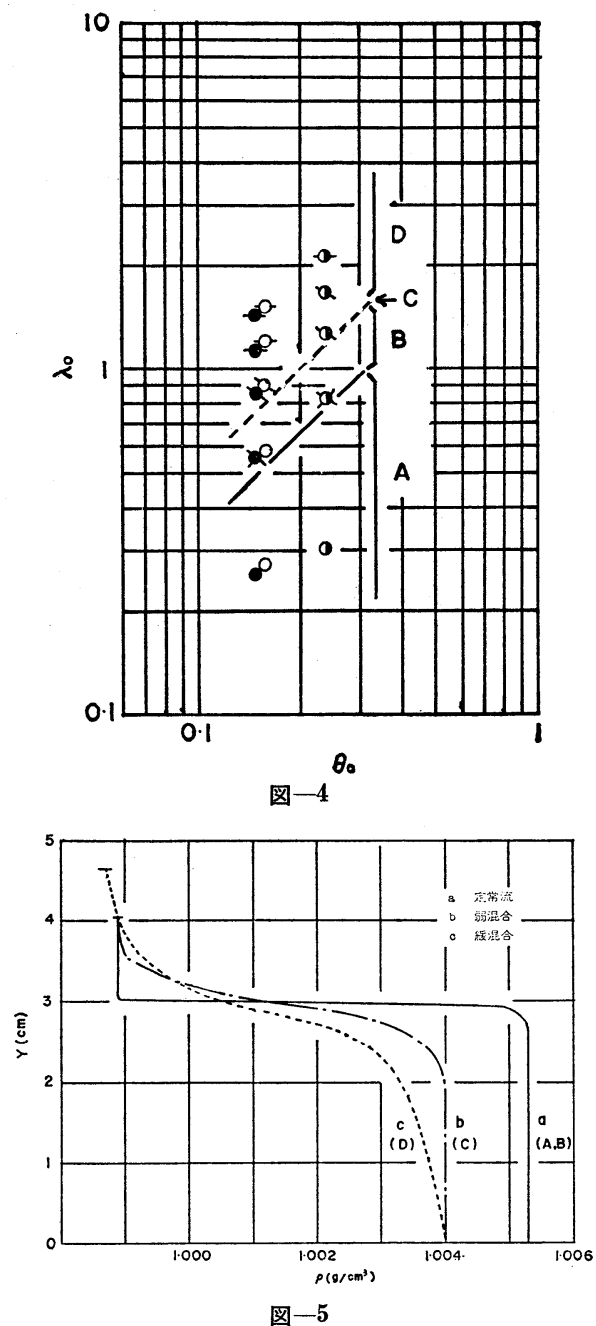

った，それぞれの混合形式に対応する概略の鉛直方向密 度構造は図一5に示されている. 分類の都合上, 直線的 な界面を A, lee wave の生じている界面を $\mathrm{B}$, 微弱な 界面破壊を C, 界面破壞がやや進えだ状態を D, 強混合

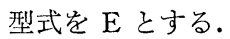

ところで, 上述の粗度条件下では, 河床から遠い下層 の流速が，ほぼ $2.0 \mathrm{~cm} / \mathrm{s}$ 以上になると粗度要素後流の 自由境界層が不安定となり，スパイラル渦の発生するこ とが分かっている，乙の臨界条件を 図一4に記入する と，同図の破線で示される．この傾向は， $\lambda_{0} \theta_{0}{ }^{-1}=$ const. で表現できるが，これは，塩水楔が河道に存在する限 り，渦の発生条件が $U_{10}$ にほとえど影響されないという ことから必然的に出てくる結果である（ $\lambda_{0}, \theta_{0}$ の分母が ともに $U_{10}$ であることを知れば理解されよう). 混合型 式の境界線も同様の傾向が見出され，しかも，スパイラ ルの発生条件と混合の開始条件が一致するという事実 は, やはり，界面破壊がスパイラル渦に基づき生ずるも のであることを示している。
ここで，図一5 の結果を解釈する上で言及すべき問題 点をいくつか述べておく. 第一点は, 図一 4,5 が浱潮最 盛時に観測されたもので，落潮期には，すべての混合型 式が安定化するということである.もう一点は，図一4, 5には強混合型式が見あたらないことである。これは， 渦が，粗度高さの 2 倍程度の直径（振幅）にしか成長で きないことと関係しており，強混合型式の確立のために は, 装置の限界をこす, さらに強い潮汐を与える必要の あることを示している（あるいは，本質的に強混合型式 にはならないのかもしれない)，いま一つ言及すべき点 は，水路が有限の長さであることと関係がある。すなわ ち, 変動流速振幅は，上流端に近いほど小さくなり，ス パイラル渦のサーキュレーションも, やはり，上流端に 近いほど弱まる点である（これについては後にデーター を示す)．この事実のために，河口付近では強い混合が 生じても, 上流域では, 粗度要素間に流入した塩水が, ほとえど混合せずに，いつまでも残留することになる。

\section{7. 粗度要素高さと混合型式}

次に, $S / H$ は 16.7 に保って, $H$ を変え，スパイラ ル渦の直径を変化させた場合の混合型式を観察してみよ う. 図一6には $H$ を $0.6 \mathrm{~cm}, 1.2 \mathrm{~cm}, 1.8 \mathrm{~cm}$ とした

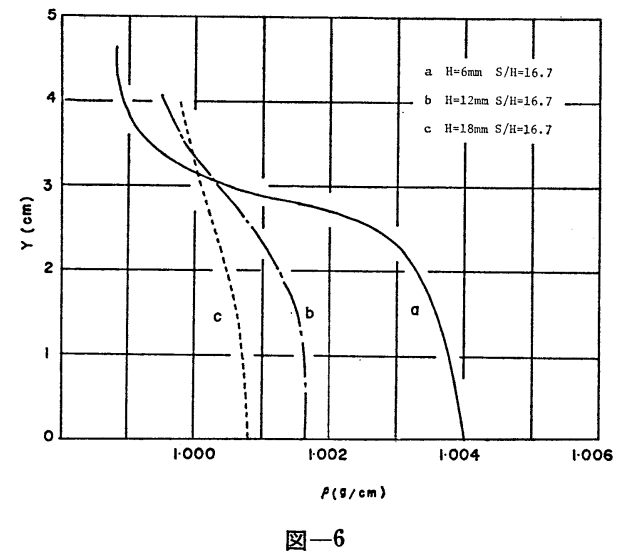

場合の鉛直密度分布が示されている．このう台 $H=0.6$ $\mathrm{cm}$ については, 図一 4,5 の最も混合の進えだ密度構造 に相当している．他の例は，これと同じ潮差を与えた場 合のもので， $H$ が大なるほど混合が進み，特に $H=1.8$ $\mathrm{cm}$ においては, いわゆる強混合型式が確立しているこ とが分かる．以上のことから，強混合型式の確立のため には, 適当な粗度間隔の他, $H$ が, 満潮時の全水深の約 半分程度になる必要があるといえる。

\section{8. 流心に沿った涨潮最盛時の密度分布}

$H=1.2 \mathrm{~cm}, S=20 \mathrm{~cm}, \varepsilon=0.0064, Q=15 \mathrm{cc} / \mathrm{s}, \eta_{10}$ $=0.5 \mathrm{~cm}$ の条件下で, 河口沖合 $16 \mathrm{~cm}$, 河口上流 $10 \mathrm{~cm}$, 


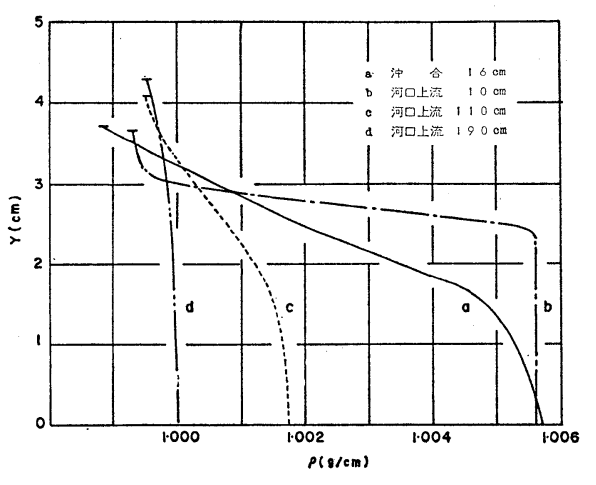

図-7

$110 \mathrm{~cm}, 190 \mathrm{~cm}$ における鉛直方向の密度分布を測定す ると, 図一7 の結果を得る, なお, 漲潮時, 混合しつつ 侵入してくる塩水塊の head は河口上流約 $200 \mathrm{~cm}$ に達 するものの，それ以上侵入しないうちに落潮期をむかえ る.したがって, 強いサーキレーションのスパイラル渦 を生じない $200 \mathrm{~cm}$ 以上上流域では粗度要素間に, 濃度 の高い塩水が残留することになる，一方，河口沖合 16 $\mathrm{cm}$ での結果をみてみると, 界面近傍の混合が目につく が，これは落潮時に河道で作られた，十分混合した水塊
が漸変密度層を形成するためであり, 河口上流 $10 \mathrm{~cm}$ で, むしろ漸变部分が無くなっている理由は, 流出塩水塊が 漲潮時に河道に戾ることができず，かわりに，周辺の混 合していない一様密度の塩水が侵入するためである.

\section{参 考 文 献}

1）吉田・柏村： 河口二層流の流れ構造の解析, 第 25 回海講 論文集, pp. 460 464, 1978.

2) 柏村 ·吉田：潮汐による河口の flow pattern の変化, 第 19 回海講論文集, pp. 103 106, 1972.

3）吉田：潮汐に対する河口二層流の応答, 北大工学部研究報 告, Vol. 85, pp. 101 114, 1977.

4) Yoshida, S. and M. Kashiwamura: Tidal response of the two-layer flow at a river mouth, Proc. 15th Conf. on Coastal Eng., Vol. 4, pp. 3189 3207, 1976.

5) 前出 2), 3), 4).

6）吉田：密度界面における波動の発生と破壞条件, 第 23 回 水講論文集, pp. 363 368, 1972.

7) Tatumi, T. and K. Gotoh: The stability of free boundary layers between two-uniform stream, J. Fluid Mech., Vol. 7, pp. 433 441, 1960.

8) Lessen, M.: On stability of free laminar boundary layer between parallel streams, NACA, Rep. 979, 1950.

9）足立昭平：人工粗度の実験的研究，土木学会論文集，104 号, 1964. 